\title{
Effect of age of plantation on seed characters and growth performance of Tokopatta (Livistona jinkensiana Griff.) seedling
}

\author{
N. Lyngdoh ${ }^{1}$, Mukul Kumar ${ }^{1 *}$ Naresh Kumar $^{2}$ and A. K. Pandey ${ }^{3}$ \\ ${ }^{1}$ Department of Tree Improvement, College of Horticulture and Forestry, Central Agricultural University, Pasighat- \\ 791102 (Arunachal Pradesh), INDIA \\ ${ }^{2}$ Department of Forest Product Utilization, College of Horticulture and Forestry, Central Agricultural University, \\ Pasighat-791102 ( Arunachal Pradesh), INDIA \\ ${ }^{3}$ Dean's Office, College of Horticulture and Forestry, Central Agricultural University, Pasighat-791102, (Arunachal \\ Pradesh), INDIA \\ *Corresponding author. E-mail: mukulbreeder@ rediffmail.com
}

Received: July 24, 2014; Revised received: September 27, 2014; Accepted: November 19, 2014

\begin{abstract}
Tokopatta palm (Livistona jinkensiana) is a valuable non timber multiple end uses forest species of Arunachal Pradesh. In order to establish improved plantation, the production of quality seedling of this species is essential. The present study was undertaken to determine tree age effects on seed characters, seed germination and performance of seedlings. The 500 seeds sample from each plantations aged 18, 25, 35, 45, 54, 63 and 74 years old around Pasighat town under East Siang district, Arunachal Pradesh, India were taken to see the effect of tree age on seed morphological characters, seed germination and seedling performance. Significant variation was observed for seed diameter and seed weight between plantations of different ages. The age effect was also seen in the germination patterns with middle aged plantations producing most superior seeds in terms of seed morphological parameters and germination behavior. Seedling attributes after 12 months showed that seedling obtained from young and middle aged plantations (between 18 to 45 years) performed better than those beyond 50 years.
\end{abstract}

Keywords: Arunachal Pradesh, Livistona jinkensiana, Mother tree age, NTFP, Seed parameters

\section{INTRODUCTION}

Livistona jinkensiana is a non-timber forest produce (NTFP) yielding palm species endemic to North East India and largely distributed in the eastern and central part of Arunachal Pradesh. The leaf commonly known as Tokopatta is traded among the tribal communities for multiple end uses and especially prized for roofing of bamboo based houses. Growers receive handsome income from sale of tokopatta with the price ranging between Rs. 200 and Rs. 300/- for a bundle consisting of 50 leaves. Besides being the source of remunerative income tokopatta also holds immense bio-cultural significance to the tribal population of the state (Singh et al., 2010).

Over decades, tokopatta palms have been cultivated in various landscapes-jhum land, paddy fields, home gardens as well as plantation in Arunachal Pradesh. Yet scientific cultivation practices of the species has never been undertaken nor studied. As an aged old practice, farmers collect seeds from existing plantations during the month of January and are stored for a period of 10 days. Prior to sowing the external pulp is removed and directly sown in the field. (Singh et al. 2010) However, selection of seed source is random depending upon the availability of seeds and ease of collection. In addition, plantations are not established by using the best seedlings since raising of tokopatta seedlings in nursery is not practiced at all. In this regard, the quality of the plantation may have been compromised to a large extent.

For production of good quality seedlings control on quality of seed is essential. The importance of age of mother trees has been long recognized as one factors contributing to the quality of seeds used for raising of seedlings (Cummings, 1947). However, much of the studies on the effect of morphology of the mother plant on seed quality and quantity have been carried out on annual species and little attention has been paid to tree species (Malcolm et al. 2003). In few of the species so far studied such as Abies nordmandiana (Vidakovich, 1991) and A. pinsapo (Gatalan and Parados, 1983) the best age for seed production is between 30 and 40 years. Moreover, trunk diameter which is a reflection of the age of trees is an important aspect in seed production which is effective in some species such as Glyricidia lucida (Guedje et al. 2003) and Tectona grandis (Mutnal et al. 2003). In one of the members of palm family, Raja et al. (2004) found that seeds collected from middle aged trees of Areca nut which were 45 years old consistently had highest shoot 
length, root length, number of roots, seedling dry weight and vigour index compared to seeds collected from trees aged 7,14,21 and 28 years. But such information on tokopatta is still lacking. Therefore, the present study was undertaken to know the influence of the mother palm age on the seedling emergence and vigour of seedlings of tokopatta an economically important NTFP species of the region.

\section{MATERIALS AND METHODS}

The experiment was conducted in the nursery of the Department of Tree Improvement, College of Horticulture and Forestry, Central Agricultural University, Pasighat Arunachal Pradesh (28 04' 40.5" $\mathrm{N}, 95^{\circ} 19^{\prime} 18.8^{\prime}$ E, 160m) situated along the bank of the might Siang river. Fresh and mature fruits of Toko palms were collected in January 2012 from plantations under different ages $(18,25,35,45,54,63$ and 74) around Pasighat. From each plantation 10 trees were selected as mother trees and 100 fruits were collected from each tree. The fruits from each plantation were thoroughly mixed and out of which 500 fruits was sampled. Out of this 100 fruits were separated for studying seed morphological characters such as seed weight and seed diameter. The rest of the fruits were given a single pre sowing treatment which consisted of removal of the black external pulp before sowing them in well prepared germination beds (Singh et al., 2010) in 4 replications of 100 seeds each. Sowing was undertaken at the last week of January, 2012 and germination was observed for the next 120 days after sowing and subsequently germination percent according to ISTA (1999) and germination value as per Czabator (1962) was calculated. Seedlings from germination experiment were transplanted into polybags after emergence of $2^{\text {nd }}$ leaf (Meerow, 1991). The seedlings were initially kept inside a shade house to minimize transplanting shock. After a week, they were transferred outdoors. At least 50 seedlings were maintained for different age class. Since tokopatta is a slow growing palm, we recorded growth and biomass parameters at 12 months old. Growth parameters included number of primary roots, diameter of main root, number of leaves and length of primary roots, were recorded on total of 15 individuals divided into 3 replications for each age. Biomass estimation included root and shoot fresh weight as well as dry weight on the same individuals.

All experiments were set up in completely randomized design. The collected data were analyzed statistically following the analysis of variance (ANOVA) technique and means were adjudged by Duncan's Multiple Range Test (DMRT) as elaborated by Duncan (1955) at $p \leq 0.05$ using DSAASTAT statistical software (version 1.101).

\section{RESULTS AND DISCUSSION}

Significant variation was observed for seed diameter and seed weight between plantations of different ages. The highest seed diameter was observed from lantation aged of 18 years $(1.35 \pm 0.01 \mathrm{~cm})$ which was statistically identical with plantation aged of 35 and 45 years old. In case of seed weight, it was observed to be maximum in plantation age of 45 years $(23.73 \pm 0.77 \mathrm{~g})$ followed by 18 years old $(22.36 \pm$ $0.53 \mathrm{~g})$ plantation which was statistically at par with 35 years age old plantation. Generally, tokopatta plams initiate to bearing from age of 10 which may be delayed up to 20 years probably depending on the site conditions. In our study, seed quality was observed to be superior in young to middle aged trees with a drastic fall in seed quality after the age of 50 years (Fig. 1). The age effect is also reflected in germination pattern of seeds from palms of more than 50 years of age (Fig. 2 and Table 1). Seeds from all sources started germinating 90 days after sowing (Fig. 2). While seeds from 35 years old plantation showed earliest germination, that of 55 years which showed most

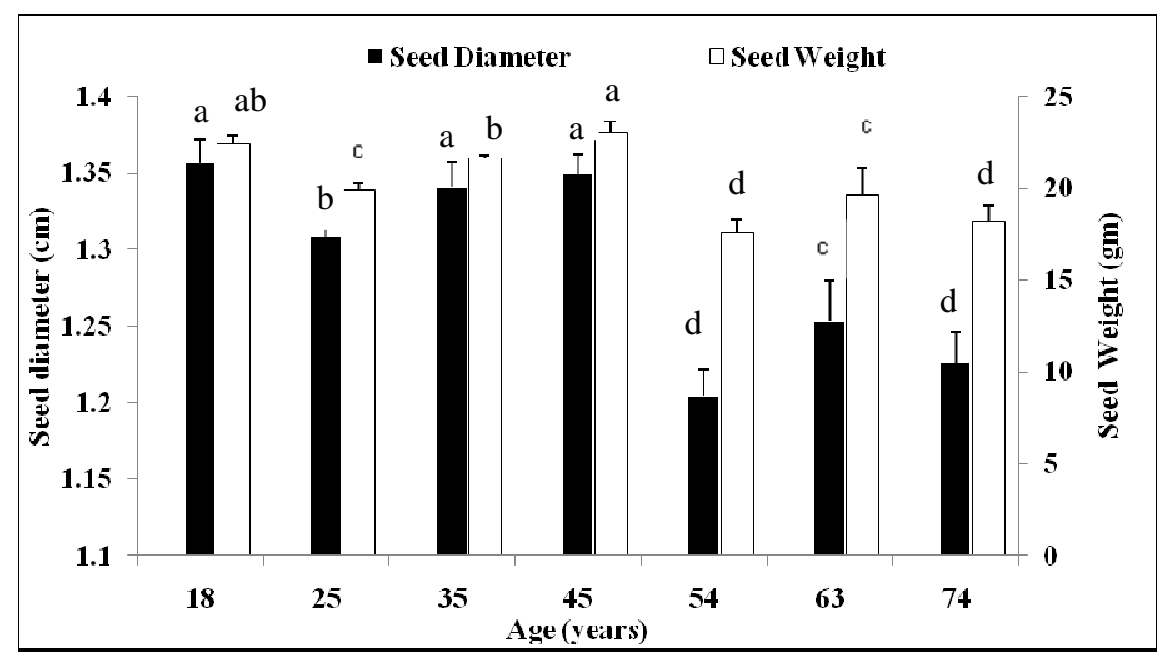

Fig. 1. Average seed diameter and average seed weight of Tokopatta palms collected from plantations of different ages (Values with same letter differ non significantly at $p<0.05$ based on DMRT). 


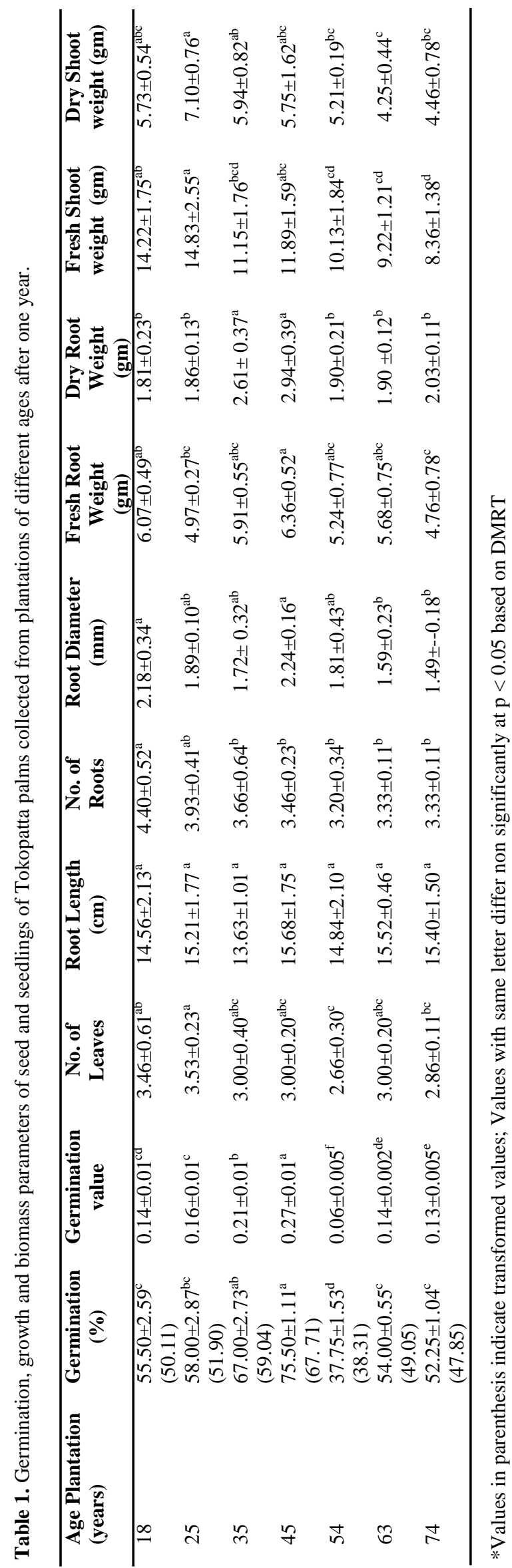

delayed germination starting only after 110 days. Highest germination was observed in seeds obtained from palms of 45 years old $(75.50 \pm 1.11 \%)$ which dropped in the successive ages. Mother tree age is known to have significant effect on seed quality and quantity. The seed production of Pinus sylvestris (Mukassabi et al. 2012) and Picea mariana (Viglas et al. 2013) increased steadily with mother tree age. In terms of quality, some tree species exhibited the highest seed germination rate in the middle age, such as Pinus echinata (Grayson et al. 2002) and Sorbus torminalis (Espahbodi et al. 2007) In general, it is recommended to collect seeds during the mid-age period of the individual. Even in palms it is advisable to select individuals which have reached the full bearing stage (Pillai, 1994).

A drastic drop in the seed traits (diameter from $1.349 \pm$ $0.01 \mathrm{~cm}$ to $1.20 \pm 0.01 \mathrm{~cm}$ and weight from $23.03 \pm$ $0.58 \mathrm{~g}$ to $17.55 \pm 0.76 \mathrm{~g}$ ) and germination percent $(75.50 \pm 1.11 \%$ to $37.75 \pm 1.53 \%)$ was observed in seeds obtained from 45 years and seeds from 54 years old plantations, respectively. However, Aiyer (1966) has reported that seed nuts were taken from trees between 25 and 30 years of age for the quality seeds in arecanut.

Growth attributes of 12 months old seedlings obtained from plantation of different ages is presented in Table 2. In general, seedling obtained from young and middle aged plantations performed better than those beyond 50 years. For all root related growth characters such as diameter of main root and root length highest values $(2.24 \pm 0.16 \mathrm{~cm}$ and $15.68 \pm 1.75 \mathrm{~cm}$, respectively) were obtained in seedlings from 45 year old plantations. Similarly, root fresh weight as well as root dry matter production were also observed to be highest $(6.36 \pm 0.52 \mathrm{~g}$ and $2.94 \pm 0.39 \mathrm{~g}$ respectively) in seedlings from 45 years old plantations. However shoot fresh weight and dry matter production was highest $(14.83 \pm 2.55 \mathrm{~g}$ and $7.10 \pm 0.76 \mathrm{~g})$ in 25 years old plantation. The results corroborate with the findings of Raja et al. (2004) for arecanut palm that showed middle aged palms produced most superior progenies in terms seed vigour. Amongst woody perennials, middle aged trees of balsam fir, Ceiba pentan$d r a$ and neem was found to have highest germination percentage, seedling dry matter and seedling vigour among the seeds from the trees of various ages (Benzie, 1960; Swaminathan et al. 1994 and Masilamani et al. 2000). In case of Pinus thunbergii, although age of mother tree did not affect seed germination but it had significant effect on relative height growth rate by altering their biomass allocation among seedlings obtained from different age classes (Mao et al. 2014). However the establishment of replicated plantation of tokopatta orchard is necessary to confirm these findings to avoid variation due to arise from local factors such as moisture status, soil condition etc. 


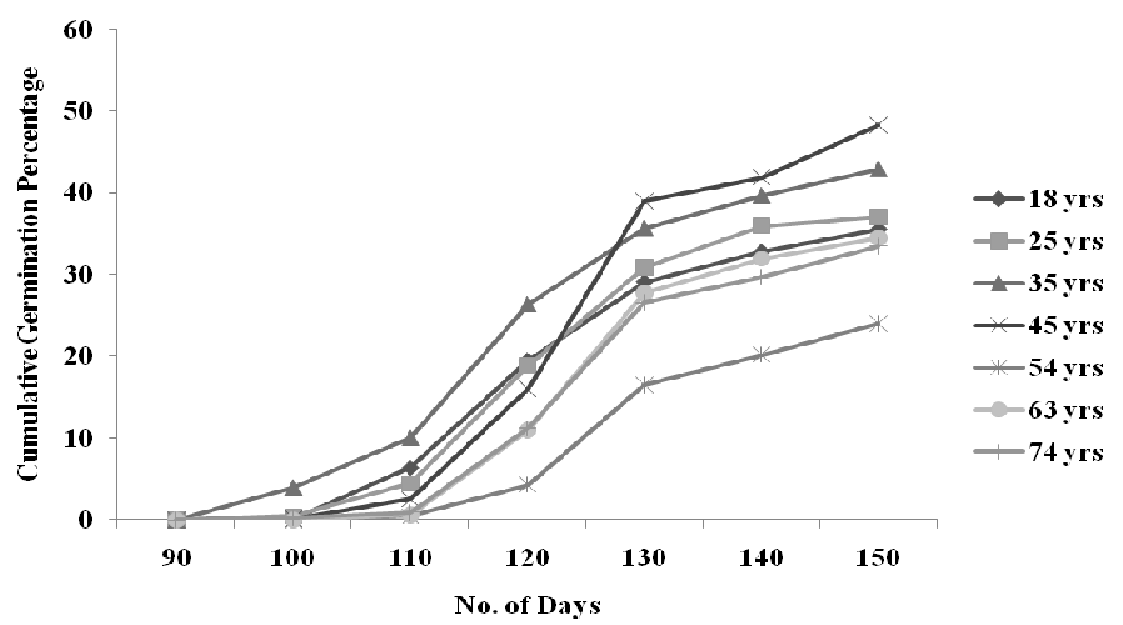

Fig. 2. Cumulative germination percentage of seeds of Tokopatta palms collected from plantations of different ages at different intervals after sowing.

\section{Conclusion}

This is perhaps the first scientific report on the cultivation aspect of tokopatta which is an economically important palm species of North East India. Based on the present findings, the selection of age of mother seed trees had significant effect on seed and seedlings attributes of planting stock. Therefore, farmers by adopting the collection of seeds from mother seed trees of young and middle age plantations (between 18 to 45 years) can have control over the quality of planting material generated in the nursery and thereby increasing the productivity of the tokopatta plantation.

\section{ACKNOWLEDGEMENTS}

Authors gratefully acknowledge the nearby villagers of East Siang District of Arunachal Pradesh for providing help to collect the seed materials from their tokopatta orchards during present investigation.

\section{REFERENCES}

Aiyer, A.K.Y.N. (1966). Field crops of India (6 ${ }^{\text {th }}$ Edn). Bangalore Printing and Publishing Co. Ltd., Bangalore.

Benzie, J.W. (1960). Viability of Balsam Fir Seed Depends on Age of Tree. Technical Note, Lake State Forest Experiment Station Note 591, pp2.

Czabator, F.J. (1962). Germination value: an index combining speed and completeness of pine seed germination. Forest Science, 8: 386-396.

Cummings, W.H. (1947). Progeny test with black locust seed from mother trees varied age and height growth. Jounal of Forestry, 45(11): 793-798.

Duncan, D.B. (1955). Multiple range and multiple F tests. Biometrics, 11: 1-42.

Espahbodi, K., Hosseini, S.M., Mirzaie-Nodoushan, H., Tabari, M., Akbarinia, M. and Dehghan-Shooraki, Y. (2007). Tree age effects on seed germination in Sorbus torminalis. Gen. Appl. Plant Physiology, 33 (1-2): 107119.

Gatalan, G. and Parados, J.A. (1983). Genetics of the pinsapo. Ann. Forest Science, 9: 185-208.
Grayson, K.J., Wittwer, R.F. and Shelton, M.G. (2002) Cone characteristics and seed quality 10 years after an uneven-aged regeneration cut in shortleaf pine stands, General Technical Reports (SRS-48), Department of Agriculture, Forest Service, Southern Research Station, Asheville, NC, USA.

Guedje, N.M., Lejoly, J., Nkongmeneck, B.A. and Jonkers, W.B.J. (2003). Populationdynamics of garcinia lucida (Clusiaceae) in cameroonian atlantic forests. Forest Ecology and Management, 177: 231-241.

ISTA (1999). International rules for seed testing. Seed Science and Technology, 21:pp288

Malcolm, P. J., Holford, P., McGlasson, W. B. and Newman, S. (2003). Temperature and seed weight affect the germination of peach rootstock seedlings. Scientia Horticulturae, 98: 247-256.

Mao, P., Han, G., Wang, G., Yu, J. and Shao, H. (2014). Effects of age and stand density of mother trees on early Pinus thunbergii seedlings establishment in the coastal zone, China. The Scientific World Journal, 2014: 1-9.

Masilamani, P., Bhaskaran, M., Chinnusamy C. and Annadurai K. (2000). Influence of age of mother tree on germination and initial vigour of Neem (Azadirachta indica). Journal of Tropical Forest Science, 12 (1): 188-19.

Meerow, A.W. (1991). Palm Seed Germination, Bulletin No. BUL274, Environmental Horticulture Department, Florida Cooperative Service, Institute of Food and Agricultural Sciences, University of Florida, pp11.

Mukassabi, T.A., Polwart, A., Coleshaw, T. and Thomas, P. A. (2012). Scots pine seed dynamics on a waterlogged site. Trees, 26: 1305-1315.

Mutnal, S.M., Patil, S.J., Hosalli, R.B. and Nadagoudar, B.S. (2003). Effect of tree age and diameter on germination of teak. Karnataka Journal of Agricultural Science, 16(3): 481- 484.

Pillai, R.V. (1994). Coconut seed production. In: Advances in Horticulture, Vol.10. Plantation and Spice Crops, Part 2 (Eds. Chadha, K.L. and Rethinam, P.). Malhotra Publishing House, New Delhi, pp.655-670.

Raja, K., Palanisamy, V. and Selvaraju, P. (2004). Effect of palm age on seed germination and seedling vigour in arecanut (Areca catechu L.). Madras Agric. Journal, 
91 (4-6): 326-328.

Singh R.K., Srivastava, R.C., Adi Community and Mukherjee T.K. (2010). Toko-Patta (Livistona jenkinsiana Griff): Adi community and conservation of culturally important endangered tree species in eastern Himalaya. Indian Journal of Traditional Knowledge, 9(2):231-242.

Swaminathan, C., Srimathi, P. and Sivagnanam, K. (1994).
Effect of tree age on germination and seed and pod quality in Ceiba pentandra Gaertn. Indian journal of Forestry, 17: 46-48

Vidakovich, M. (1991). Conifers, morphology and variation. Graficki Zavod Hrvatske, Coroatia, Zagreb, p745.

Viglas, J.N., Brown, C.D. and Johnstone, J.F. (2013). Age and size effects on seed productivity of northern black spruce. Canadian J. of Forest Res., 43: 534-543. 